\title{
PENGARUH LATIHAN HOOPING DALAM MENINGKATKAN KEMAMPUAN LOMPAT JANGKIT PADA SISWA SMP OLAHRAGA NEGERI SRIWIJAYA PROVINSI SUMATERA SELATAN
}

\author{
Oleh: Yogi Metra, M.Pd \\ (Dosen Universitas PGRI Palembang) \\ yogimetra@yahoo.co.id
}

\begin{abstract}
Abstrak
Masalah dalam penelitian ini adalah pada saat mengikuti pembelajaran pendidikan jasmani khususnya mate lompat jangkit, secara umum rata-rata siswa kelas VIII tidak dapat mengikuti dengan baik. Tujuan Penelitian ini adalah untukmengetahuiapakah adapeningkatanyang signifikans kemampuan lompat jangkit melalui pemberian latihan hooping pada siswa SMP Olahraga Negeri Sriwijaya Propinsi Sumatera Selatan.Sampel yang diambil adalah dari proportional sampling 1 (satu) kelas jumlah siswa keseluruhan 22 siswa, Apabila subjek kurang dari 100 lebih baik diambil semua sehingga penelitian merupakan penelitian populasi. Berdasarkan hasil penelitian terdapat perbandingan nilai latihan hooping dengan kemampuan lompat jangkit pada siswa SMP Olahraga Negeri Sriwijaya Sumatera Selatan Tahun ajaran 2011-2012. Dari data hasil kemampuan lompat jangkit siswa, diperoleh rata-rata hasil kemampuan siswa pada kelompok eksperimen lebih tinggi yaitu sebesar 5,77 dibandingkan dengan kelas kontrol yaitu 5,76. Berdasarkan perhitungan statistik, pengaruh latihan hooping terhadap kemampuan lompat jangkit pada siswa SMP Olahraga Negeri Sriwijaya Sumatera Selatan dapat dilihat dari uji hipotesis yang ditunjukkan dengan $t$ hitung $=$ 2,16 dan $t$ tabel $=1.72$. Dengan demikian $t$ hitung $>t$ tabel maka Ho ditolakdan Ha diterima secara signifikan, maka dapat diartikan bahwa terdapat pengaruh latihan hooping terhadap peningkatan kemampuan lompat jangkit pada siswa SMP Olahraga Negeri Sriwijaya Propinsi Sumatera Selatan.
\end{abstract}

Kata Kunci: Latihan Hopping dan Lompat Jangkit

\section{THE EFFECT OF HOOPING EXERCISE IN IMPROVING SKIN LEARNING ABILITY IN STUDENTS OF STATE PRIVATE SRIWIJAYA SOUTH SUMATERA PROVINCE}

\begin{abstract}
The problem in this study is that when participating in physical education learning, especially jumping outbreak mate, in general the average grade VIII student cannot follow well. The purpose of this study was to determine whether there was a significant increase in the ability to jump outbreak through the provision of hooping exercises to students of Sriwijaya State Sports Middle School in South Sumatra Province. The sample taken is from proportional sampling 1 (one) class the total number of students is 22 students. If the subject is less than 100 it is better to take all of it so that the research is a population study. Based on the results of the study there is a comparison of the value of hooping exercises with the ability to jump jump in Middle School Sriwijaya State High School students of South Sumatra 2011-2012 academic year. From the data of
\end{abstract}


the jumping ability of students, the average results obtained by the ability of students in the experimental group is 5.77 compared to the control class of 5.76. Based on statistical calculations, the effect of hooping exercises on the jump jumping ability of South Sumatra Sriwijaya State Sports Middle School students can be seen from the hypothesis test shown by $t$ count $=2.16$ and t table $=1.72$. Thus tcount $>$ ttable, then Ho is rejected and Ha is accepted significantly, it can be interpreted that there is an effect of hooping training on increasing jumping ability of students in Sriwijaya State Sports Middle School, South Sumatra Province

Keywords: Hopping training and triple Jump

Correspondence author: Yogi Metra, Universitas PGRI Palembang, Indonesia. E-Mail: yogimetra@yahoo.co.id (c) (i) (2)

Jurnal HalamanOlahraga Nusantara licensed under a Creative Commons Attribution-ShareAlike 4.0 International License.

\section{PENDAHULUAN}

Olahraga merupakan bagian proses pendidikan yang dapat memberikan sumbangan berharga bagi pertumbuhan dan perkembangan peserta didik, adapun manfaat dari olahraga diantaranya yaitu meningkatkan kesegaran jasmani. Hal ini sesuai dengan Undang-Undang Republik Indonesia Nomor 3 Tahun 2005 tentang Sistem Keolahragaan Nasional Pasal 3 dan pasal 4 sebagai berikut:

Keolahragaan nasional berfungsi mengembangkan kemampuan jasmani, rohani, dan sosial serta membentuk watak dan kepribadian bangsa yang bermartabat, dan pasal 4 menyebutkan bahwa keolahragaan nasional bertujuan memelihara dan meningkatkan kesehatan dan kebugaran, prestasi, kualitas manusia, menanamkan nilai moral dan akhlak mulia, sportivitas, disiplin, mempererat dan membina persaudaraan dan kesatuan bangsa, memperkukuh ketahanan nasional, serta mengangkat harkat, martabat, dan kehormatan bangsa.

Memperhatikan secara umum fungsi serta tujuan dari olahraga di atas, maka melalui kegiatan olahraga akan dapat mengembangkan jasmani, rohani serta pembentukan watak dan martabat untuk menopang kepribadian bangsa. Selain itu melalui olahraga akan dapat meningkatkan kesehatan, kebugaran, prestasi dan 
membentuk kualitas manusia yang berahlak mulia dengan mengutamakan kesatuan dan persatuan serta mengangkat kehormatan bangsa. Pendidikan jasmani adalah proses interaksi antara peserta didik dan lingkungan yang dikelola melalui aktivitas jasmani dalam upaya menuju pembentukan manusia Indonesia seutuhnya. (Syarifudin, 1992)

Pelajaran pendidikan jasmani yang diberikan dari tingkat Sekolah Dasar, Sekolah Menengah Pertama dan tingkat Sekolah Menengah Atas meliputi atletik, permainan, senam, beladiri dan kesehatan. Pembelajaran atletik itu sendiri masih ada yang belum sesuai dengan yang diharapkan, mengingat cabang olahraga tersebut kurang menarik perhatian siswa dibandingkan dengan cabang olahraga permainan, dengan alasan bahwa pembelajaran atletik tersebut hanya terpaku pada pokok bahasan saja tanpa adanya modikasi sehingga akan menimbulkan kejenuhan bagi siswa, disamping itu lebih dikarenakan pada faktor-faktor peralatan dan fasilitas yang kurang memungkinkan (Riyadi, 1985).

Atletik merupakan salah satu cabang olahraga yang sangat penting, sebab dalam unsur atletik tersebut mengandung gerakan-gerakan dasar dari hampir semua cabang olahraga yang kita kenal. Dengan demikian pemberian materi pelajaran pendidikan jasmani pokok bahasan atletik di Sekolah Menengah Pertama akan lebih menarik minat dan perhatian siswa bila dikembangkan serta dimasukkan pada unsur permainan atau yang lebih tepat yaitu "atletik dalam permainan". Atletik adalah gabungan dari beberapa jenis olahraga yang secara garis besar dapat dikelompokkan menjadi lari, lempar, dan lompat. Kata ini berasal dari bahasa Yunani "athlon" yang berarti "kontes". Atletik merupakan 
cabang olahraga yang diperlombakan pada olimpiade pertama pada 776 SM. Induk organisasi untuk olahraga atletik di Indonesia adalah PASI (Persatuan Atletik Seluruh Indonesia).

Lompat jangkit adalah bagian dari cabangolahraga atletik di mana seseorang akanmelakukan kegiatan dengan rangkaian awalan, tolakan (melakukan jingkat) melayang dan mendarat sejauh mungkin. Pelaksanaan perlombaan akan berlari di jalur biasanya mempunyai permukaan yang sama dengan lintasan lari dan melompat sejauh yang boleh dengan menginjak pada papan kayu pada bagian yang diisi pasir.

Jarak minimum dari papan ke tanda yang dibuat oleh atlit pada pasir diukur. Jika seseorang itu melakukan lompatannya dengan bagian kakinya di depan atau melebihi papan (satu lapisan plastisin diletakkan dengan segera di depan papan untuk mengesan ketepatan ini), lompatannya diinyatakan sebagai hasil tidak memenuhi syarat kualifikasi atau perlombaan (disqualifikasi). Format sebenarnya perlombaan ini berbeda, tetapi secara umum peserta akan mendapat beberapa kali lompatan yaitu untuk membuat lompatan dan hanya lompatan yang terpanjang akan dinyatakan sebagai hasil akhir

Suatu akivitas gerakan yang dilakukan di dalam lompatan untuk mencapai hasil lompatan yang sejauh-sejauhnya maka dibutuhkan komponen fisik yang baik. Kualitas fisik dimaksud adalah kualitas dan komponen fisik sangat spesifik dalam lari jarak pendek yaitu meliputi kecepatan, kekuatan, daya ledak, koordinasi dan daya tahan anaerobik. (Bompa, 1990) 
Ukuran bak lompat jauh atau lompat jangkit untuk jarak awalan lari sampai balok tumpuan 45 meter, balok tumpuan tebal $10 \mathrm{~cm}$, panjang 1,22 meter, lebar $30 \mathrm{~cm}$, bak lompatan panjang 9 meter dan lebar 2.75 meter, serta kedalaman bak lompat \pm 1 meter. Sedangkan atau tumpuan atau tolakan serta saat badan saat berada diudara dan melakukan pendaratan di bak pasir dengan mendorongkan anggota badan kedepan.Dengan dengan demikian seorang pelatih juga dituntut untuk memahami tentang ilmu melatih yang berkaitan dengan prinsip-prinsip latihan, yang mengacu pada pembinaan olahraga prestasi dengan menggunakan metode yang tepat.

Secara keseluruhan di SMP Olahraga Negeri Sriwijaya Propinsi Sumatera Selatan para siswanya telah memiliki kemampuan bidang olahraga masing-masing seperti cabang olahraga atletik terdiri dari nomor-nomor lari dan jalan cepat, bola voli, sepak bola, sepak takraw, tenis meja, panahan, dayung, senam, pencak silat dan taekwondo, akan tetapi apabila pada saat mengikuti pembelajaran pendidikan jasmani khususnya materi lompat jangkit, secara umum rata-rata siswa kelas VIII tidak dapat mengikuti dengan baik.Alasan ini timbul dikarenakan pembelajaran pendidikan jasmani hanya diberikan selama 2 jam perminggu dan harus menyelesaikan materi yang terdapat di kurikulum, di samping itu dalam satu kelas terdiri dari beberapa siswa dengan cabang olahraga berlainan.

Sedangkan prestasi lompat jangkit putera di Sekolah Olahraga khususnya pada Kejurnas Atletik Yunior dan Remaja tahun 2007 di Jakarta hanya memperoleh peringkat ke tujuh dari 16 peserta, dengan demikian banyak sekali yang harus dipersiapkan dan di latih untuk memperoleh prestasi yang maksimal. 
Memperhatikan keadaan di atas maka penulis mengadakan penelitian yang berjudul "Pengaruh Latihan Hooping Dalam Meningkatkan Kemampuan Lompat Jangkit Pada Siswa SMP Olahraga Negeri Sriwijaya Provinsi Sumatera Selatan”.

\section{METODE}

Penelitian ini termasuk penelitian eksperimental lapangan dengan menggunakan rancangan "the pre test - post test control groups desaign" (Sugiyono, 2008, p. 43), seperti yang dilukiskan sebagai berikut:

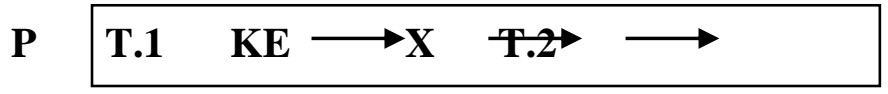

Keterangan:

$\mathrm{P}=$ populasi

$\mathrm{T} .1=$ tes awal

$\mathrm{KE}=$ kelompok Eksperimen

$\mathrm{X}=$ perlakuan

$\mathrm{T} .2=$ tes akhir

Teknik analisis data terhadap uji intsrumen (pretest - post test) dalam penelitian ini adalah Uji normalitas dengan Chi kuadrat, Uji homogenitas dan Uji hipotesis

\section{HASIL DAN PEMBAHASAN}

Hasil analisis data pada uji normalitas baik data hasil tes awal maupun data hasil tes akhir, baik bagi kelompok eksperimen maupun bagi kelompok kontrol semua data berdistribusi tidaknormal. Permasalahan tersebut didasari oleh kemiringan kurva yang diperoleh data antara -1 dengan +1 . (Riduwan, 2006, p. 
194). Disebutkan bahwa dalam penghitungan jika $-1<\mathrm{Km}<+1$ maka distribusi dianggap normal, dengan demikian dapat dikatakan bahwa data hasil uji normalitas di atas dianggap berdistribusi tidak normal.

Kemudian pada uji hipotesis diperoleh hasil t hitung adalah 2,16, kemudian t tabel dengan taraf kepercayaan $95 \%$ untuk jumlah sampel 22 adalah 1,72 bahwa apabila $t_{\text {hitung }}$ lebih kecil atau sama dengan $t_{\text {tabel}}$, maka Ho diterima dan Ha ditolak dan sebaliknya $t_{\text {hitung }}$ lebih besar atau sama dengan $t_{\text {abel}}$, maka Ho ditolak dan Ha diterima. Sehingga dengan demikian dapat dikatakan bahwa ada pengaruh latihan Hooping terhadap peningkatan kemampuan lompat jangkit pada siswa di SMP Olahraga Negeri Sriwijaya Propinsi Sumatera Selatan.

\section{KESIMPULAN}

Berdasarkan perhitungan statistik, pengaruh latihan hoopingt erhadap kemampuan lompat jangkit pada siswa SMP Olahraga Negeri Sriwijaya Sumatera Selatan dapat dilihat dari uji hipotesis yang ditunjukkan dengant hitung $=2$, $16 \mathrm{dan} t$

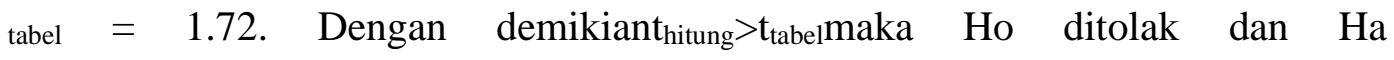
diterimasecarasignifikan, maka dapat diartikan bahwa terdapat pengaruh latihan hooping terhadap peningkatan kemampuan lompatj angkit pada siswa SMP Olahraga Negeri Sriwijaya Propinsi Sumatera Selatan.

\section{DAFTAR PUSTAKA}

Bompa, T. O. (1990). Theory and Methodology of Training. Ontorio: New York University.

Riduwan. (2006). Dasar-Dasar Statistika. Bandung: Alfabeta.

Riyadi, T. (1985). Petunjuk Atletik. Yogyakarta: FPOK - FKIP Yogyakarta. Sugiyono. (2008). Metode Penelitian Pendidikan, Pendekatan Kuantitafif, dan 
Yogi Metra, (2020)

Pengaruh Latihan Hooping Dalam Meningkatkan Kemampuan Lompat Jangkit Pada Siswa Smp Olahraga Negeri Sriwijaya Provinsi Sumatera Selatan

$R \& D$. Bandung: Alfabeta.

Syarifudin, A. (1992). Atletik. Jakarta: Departemen Penelitian dan Kebudayaan Direktorat Jenderal Tenaga Pendidikan. 